\title{
OXIDATIVE AND ANTIOXIDATIVE EFFECTS OF DESFLURANE AND SEVOFLURANE ON RAT TISSUE IN VIVO
}

\author{
Hülya TÜRKAN ${ }^{1}, \mathrm{Ahmet}_{\mathrm{AYDIN}}^{2}$, Ahmet $\mathrm{SAYAL}^{2}$, Ayșe EKEN², Cemal AKAY², \\ and Bensu KARAHALİ ${ }^{3}$ \\ Anaesthesiology and Reanimation Clinic, Kasimpasa Military Hospital, Istanbul', Gülhane Military \\ Medical Academy², Gazi University Faculty of Pharmacy, Ankara ${ }^{3}$, Turkey
}

\author{
Received in February 2011 \\ CrossChecked in May 2011 \\ Accepted in May 2011
}

\begin{abstract}
General anaesthetics are often used in patients who are under oxidative stress due to a critical illness or surgical trauma. Some anaesthetics may worsen oxidative stress and some may act as antioxidants. The aim of this study was to evaluate liver, brain, kidney, and lung tissue oxidative stress in rats exposed to desflurane and sevoflurane and in unexposed rats. The animals were divided in three groups: control (received only air); sevoflurane ( $8 \%$ ), and desflurane (4\%). After four hours of exposure, we evaluated the levels of malondialdehyde (MDA), superoxide dismutase (SOD), glutathione peroxidase (GSH-Px), $\mathrm{Cu}$, and $\mathrm{Zn}$. Exposure to either of the anaesthetics significantly increased lung MDA levels compared to control (Mann-Whitney $\mathrm{U}$ test; $\mathrm{P}<0.05$ ), probably because it is the tissue directly exposed to anaesthetic gases. Oxidative stress and antioxidant activity in other tissues varied between the desflurane and sevoflurane groups. Our results suggest that anaesthesiologist should not only be aware of the oxidative or antioxidative potential of anaesthetics they use, but should also base their choices on organs which are the most affected by their oxidative action.
\end{abstract}

KEY WORDS: $C u$, glutathione peroxidase, malondialdehyde, reactive oxygen species, superoxide dismutase, volatile anaesthetics, $\mathrm{Zn}$

Free radicals are products of normal aerobic metabolism (1). If free radical production exceeds antioxidant cell activity, this is defined as oxidative stress, which impairs cell membrane, damages DNA, and contributes to all inflammatory diseases (2).

Volatile anaesthetics cause an ischemiareperfusion $(I / R)$ injury, which is a complex phenomenon resulting in greater production of reactive oxygen species (ROS). Eroglu et al. (3) have clearly demonstrated increase in inflammatory mediators, $\mathrm{I} / \mathrm{R}$ injury, and ROS in generalised inflammatory reactions involving the production of leukocytes. Airway inflammation appears to play a central role in the development of lung diseases such as asthma and chronic obstructive pulmonary disease, and Rükgauer et al. (4) demonstrated increased oxidative stress in the blood of these patients (4).

Malondialdehyde (MDA) is an end-product of the degradation of polyunsaturated lipids by ROS (2) and is used as a biomarker of oxidative stress. On the other hand, the most common markers of cell antioxidant activity are the enzymes superoxide dismutase (SOD) and glutathione peroxidase (GSH-Px). In addition trace elements such as $\mathrm{Cu}$ and $\mathrm{Zn}$ contribute to antioxidant enzymatic activity (5).

Patients with an imbalance between ROS production and antioxidant activity due to surgical trauma are a specific population at risk. Therefore, when these 
patients are to be anaesthetised, it is important to select an anaesthetic which will burden their antioxidant defences the least.

Sevoflurane $(2,2,2-\mathrm{triflu}$ oro- 1 [trifluoromethyl]ethyl fluoromethyl ether) and desflurane (2,2,2-trifluoro-1-fluoroethyldifluoromethyl ether) are very common volatile anaesthetics used for general anaesthesia. Desflurane acts the most rapidly among volatile anaesthetics due to its low solubility in blood (6), which is related to its lowest blood-gas partition coefficient (7). In addition, it metabolises far less to $\mathrm{F}^{-}$compounds than sevoflurane (8). Ideally, a volatile anaesthetic should provide smooth and reliable induction and maintenance of general anaesthesia with minimal effects on other organ systems.

The purpose of our study was to investigate the levels of oxidative stress induced by sevoflurane and desflurane in rats using MDA as a marker of oxidative stress and enzymes SOD and GSH-Px (and their cofactors $\mathrm{Cu}$ and $\mathrm{Zn}$ ) as markers of antioxidative activity. We also tried to evaluate tissue-specific variations between rat liver, kidney, brain, and lung.

\section{MATERIALS AND METHODS}

The study protocol was approved by the Animal Care and Utilization Committee of the Gulhane Military Medical Academy (GMMA) School of Medicine, Ankara, Turkey.

\section{Animals}

The study included 21 male Wistar rats (300 g to $365 \mathrm{~g}$ body weight) obtained from the GMMAAnimal Research Facility. The rats were housed in cages under standard hygienic conditions, with light and dark cycles exchanging every $12 \mathrm{~h}$. They received standard rat feed and had free access to water.

\section{Experimental design}

The rats were randomised into three groups of seven: unexposed control, sevoflurane, and desflurane group. The animals were placed in a vented seven-litre inhalation chamber. Vented chambers provide optimal temperature, humidity, and inhaled gas composition. The chamber was preheated to maintain animal body temperature. After closing the lid, the rats were exposed to $3.5 \%$ to $4 \%$ sevoflurane or $7 \%$ to $8 \%$ desflurane vaporised at a continuous oxygen flow of
$3 \mathrm{~L} \mathrm{~min}^{-1}$ until they lost the righting reflex. Constant vacuum above the chamber was used to capture excess gas and when the animals lost the righting reflex, sevoflurane or desflurane concentrations were lowered to allow the animals to breathe spontaneously. Anaesthesia continued for four hours during which we monitored animal movement and breathing. At the end of the anaesthesia, the rats were decapitated, and their brains, lungs, livers, and kidneys collected and fixed with formol. Tissue samples were minced and homogenised in a cold potassium chloride $(\mathrm{KCl})$ solution $(1.15 \%)$ and centrifuged at 4,400 rpm and $+4{ }^{\circ} \mathrm{C}$ for 15 minutes. The supernatants were then used to analyse MDA, SOD, GSH-Px, $\mathrm{Cu}$, and $\mathrm{Zn}$, as described below.

\section{Biochemical analysis of oxidant/antioxidant parameters}

All chemicals and reagents were purchased from Sigma-Aldrich (St. Luis, USA) and Merck (Darmstadt, Germany). $\mathrm{Cu}, \mathrm{Zn}-\mathrm{SOD}$, GSH-Px, and MDA were measured using a Shimadzu UV-2100S spectrophotometer (Kyoto, Japan).

$\mathrm{Cu}, \mathrm{Zn}-\mathrm{SOD}$ activities in supernatant were measured using a method described earlier $(9,10)$. Briefly, $50 \mu \mathrm{L}$ of supernatant was mixed with $850 \mu \mathrm{L}$ of substrate solution containing $0.05 \mathrm{mmol} \mathrm{L}^{-1}$ xanthine sodium and $0.025 \mathrm{mmol} \mathrm{L}^{-1}$ 2-(4-iodophenyl)3-(4-nitrophenol)-5-phenyltetrazolium chloride (INT) in a buffer solution containing $50 \mathrm{mmol} \mathrm{L}^{-1}$ CAPS (3-(cyclohexylaminol)-1-propanesulfonic acid) and $0.094 \mathrm{mmol} \mathrm{L}^{-1}$ EDTA (pH 10.2). One hundred microlitres of xanthine oxidase $\left(80 \mathrm{U} \mathrm{L}^{-1}\right)$ was added to the mixture and increase in absorbance was observed at $505 \mathrm{~nm}$ for $3 \mathrm{~min}$.

GSH-Px activities in supernatant were measured using a method described earlier (10). Briefly, we prepared a reaction mixture containing $1 \mathrm{mmol} \mathrm{L}^{-1}$ $\mathrm{Na}_{2}$ EDTA, $2 \mathrm{mmol} \mathrm{L}^{-1}$ reduced glutathione, $0.2 \mathrm{mmol} \mathrm{L}^{-1} \mathrm{NADPH}, 4 \mathrm{mmol} \mathrm{L}^{-1}$ sodium azide, and $1000 \mathrm{U}$ glutathione reductase in $50 \mathrm{mmol} \mathrm{L}^{-1}$ TRIS buffer ( $\mathrm{pH}$ 7.6). Fifty microlitres of the supernatant and $950 \mu \mathrm{L}$ of the reaction mixture were mixed and incubated at $37^{\circ} \mathrm{C}$ for $5 \mathrm{~min}$. The reaction was initiated by adding $8.8 \mathrm{mmol} \mathrm{L}^{-1}$ hydrogen peroxide and a decrease in absorbance was recorded at $340 \mathrm{~nm}$ for $3 \mathrm{~min}$.

Lipid peroxidation was determined by measuring MDA, using the method described by Jain (10). Tetramethoxy propane solution was used as standard. This assay is based on the formation of red adduct in 
acidic medium between thiobarbituric acid and MDA; the product of lipid peroxidation was measured at $532 \mathrm{~nm}$.

For $\mathrm{Cu}$ and $\mathrm{Zn}$ measurements, tissue samples were digested with a mixture of nitric acid and hydrogen peroxide in a Milestone microwave digestor Mega 1200 (Bergamo, Italy) and $\mathrm{Cu}$ and $\mathrm{Zn}$ determined with a flame atomic absorption spectrometer (Varian SpectraAA30/40, Mulgrave, Australia) according to the instrument procedure (11). The flame was an airacetylene mixture. The calibration curve interval for $\mathrm{Cu}$ was (2 to 6) $\mu \mathrm{g} \mathrm{mL}^{-1}$ and for $\mathrm{Zn}(0.5$ to 1.5$) \mu \mathrm{g} \mathrm{mL}^{-1}$.

\section{Statistical analysis}

For statistical analysis we used SPSS statistics software (version 13.0). Data were expressed as medians and ranges. The differences between the groups were compared using the Mann-Whitney U test. A P value of less than 0.05 was considered statistically significant.

\section{RESULTS}

All animals completed the experiment, that is, all survived until sacrifice.

\section{MDA concentrations}

Compared to controls, MDA significantly dropped in the sevoflurane group liver, kidney, and brain and in the desflurane group liver. However, they significantly increased in the lungs of both anaestheticexposed groups. MDA in the desflurane group was slightly higher than in the sevoflurane group in the liver and lung, but the differences were not significant (Table 1).

\section{SOD and GSH-Px concentrations}

The only significant differences from control were higher brain and lower liver SOD in the desflurane group. The sevoflurane group showed no significant differences in SOD concentrations from control (Table 2).

Table 1 MDA levels in the liver, kidney, brain, and lung tissues of rats exposed to sevoflurane and desflurane

\begin{tabular}{|c|c|c|c|c|}
\hline \multirow{2}{*}{ Tissue } & & \multicolumn{3}{|c|}{ MDA / nmol g $^{-1}$} \\
\hline & & Sevoflurane Group & Desflurane Group & Control Group \\
\hline \multirow{2}{*}{ Liver } & Median & $1.36^{*}$ & $1.19 *$ & 1.72 \\
\hline & Range & 1.29 to 1.53 & 1.06 to 1.62 & 1.20 to 2.97 \\
\hline \multirow{2}{*}{ Kidney } & Median & $1.54^{*}$ & 2.11 & 2.11 \\
\hline & Range & 1.33 to 1.64 & 1.42 to 2.53 & 1.46 to 2.35 \\
\hline \multirow{2}{*}{ Brain } & Median & $0.89^{*}$ & 0.95 & 1.01 \\
\hline & Range & 0.82 to 0.95 & 0.88 to 1.01 & 0.91 to 1.07 \\
\hline \multirow{2}{*}{ Lung } & Median & $1.08^{*}$ & $1.06^{*}$ & 0.92 \\
\hline & Range & 0.91 to 1.32 & 0.97 to 1.12 & 0.85 to 1.03 \\
\hline
\end{tabular}

Each group consisted of 7 rats

* different from control P<0.05, Mann - Whitney U test

Table 2 SOD levels in the liver, kidney, brain, and lung tissues of rats exposed to sevoflurane and desflurane

\begin{tabular}{|c|c|c|c|c|}
\hline \multirow{2}{*}{ Tissue } & & \multicolumn{3}{|c|}{ SOD / U $\mathbf{g}^{-1}$} \\
\hline & & Sevoflurane Group & Desflurane Group & Control Group \\
\hline \multirow{2}{*}{ Liver } & Median & 1729 & $1575^{*}$ & 1897 \\
\hline & Range & 1192 to 1987 & 1435 to 1811 & 1308 to 2082 \\
\hline \multirow{2}{*}{ Kidney } & Median & 1248 & 1192 & 1137 \\
\hline & Range & 492 to 1370 & 257 to 1503 & 566 to 1192 \\
\hline \multirow{2}{*}{ Brain } & Median & 194 & $269^{*}$ & 185 \\
\hline & Range & 116 to 223 & 111 to 373 & 566 to 1192 \\
\hline \multirow{2}{*}{ Lung } & Median & 161 & 185 & 161 \\
\hline & Range & 128 to 234 & 111 to 245 & 122 to 213 \\
\hline
\end{tabular}

Each group consisted of 7 rats

* different from control $P<0.05$, Mann - Whitney U test 
As for GSH-Px, only the sevoflurane group kidney tissue showed significantly lower levels, but even these were within the control range. There were no other significant changes in either group (Table 3 ).

\section{$\mathrm{Zn}$ and $\mathrm{Cu}$ levels}

Zinc was significantly higher in the lung and kidney tissues of the desflurane group and only in the lung tissue of the sevoflurane group (Table 4). The only significant change in $\mathrm{Cu}$ levels was a drop in the lung tissue of the desflurane group (Table 5).

\section{DISCUSSION}

Oxidative stress occurs in many human diseases and significantly contributes to their development (12). The protective action of drugs against oxidative stress

Table 3 GSH-Px levels in the liver, kidney, brain, and lung tissues of rats exposed to sevoflurane and desflurane

\begin{tabular}{llccc}
\hline \multirow{2}{*}{ Tissue } & & \multicolumn{3}{c}{ GSH-Px $/ \mathbf{U} \mathbf{~ g}^{-1}$} \\
\cline { 2 - 5 } & & Sevoflurane Group & Desflurane Group & Control Group \\
\hline \multirow{2}{*}{ Liver } & Median & 82.07 & 70.00 & 67.68 \\
\cline { 2 - 5 } & Range & 60.75 to 92.73 & 55.54 to 77.77 & 17.77 to 90.74 \\
\multirow{2}{*}{ Kidney } & Median & $43.39^{*}$ & 54.14 & 47.94 \\
\cline { 2 - 5 } & Range & 37.19 to 48.35 & 46.12 to 65.21 & 37.44 to 67.61 \\
\hline \multirow{2}{*}{ Brain } & Median & 61.74 & 70.83 & 64.88 \\
\hline \multirow{2}{*}{ Lung } & Range & 56.61 to 73.72 & 62.73 to 78.02 & 53.14 to 72.89 \\
\hline
\end{tabular}

Each group consisted of 7 rats

* different than control $P<0.05$, Mann - Whitney U test

Table 4 Zn levels in the liver, kidney, brain, and lung tissues of rats exposed to sevoflurane and desflurane

\begin{tabular}{|c|c|c|c|c|}
\hline \multirow{2}{*}{ Tissue } & & \multicolumn{3}{|c|}{$\mathrm{Zn} / \mu \mathrm{gg}^{-1}$} \\
\hline & & Sevoflurane Group & Desflurane Group & Control Group \\
\hline \multirow{2}{*}{ Liver } & Median & 27.06 & 25.62 & 26.61 \\
\hline & Range & 22.50 to 30.15 & 19.95 to 29.52 & 18.60 to 30.78 \\
\hline \multirow{2}{*}{ Kidney } & Median & 22.26 & $22.89 *$ & 20.46 \\
\hline & Range & 14.43 to 24.69 & 20.49 to 24.33 & 15.48 to 22.41 \\
\hline \multirow{2}{*}{ Brain } & Median & 6.36 & 7.08 & 6.39 \\
\hline & Range & 5.43 to 15.72 & 4.80 to 11.40 & 4.95 to 11.22 \\
\hline \multirow{2}{*}{ Lung } & Median & $11.37^{*}$ & $10.64 *$ & 9.51 \\
\hline & Range & 9.36 to 14.97 & 9.82 to 11.91 & 6.91 to 11.43 \\
\hline
\end{tabular}

Each group consisted of 7 rats

* different than control P<0.05, Mann - Whitney U test

Table $5 \mathrm{Cu}$ levels in the liver, kidney, brain, and lung tissues of rats exposed to sevoflurane and desflurane

\begin{tabular}{llccc}
\hline \multirow{2}{*}{ Tissue } & & \multicolumn{3}{c}{$\mathbf{C u} / \boldsymbol{\mu g ~ g}^{-1}$} \\
\cline { 2 - 5 } & & Sevoflurane Group & Desflurane Group & Control Group \\
\hline \multirow{2}{*}{ Liver } & Median & 2.70 & 3.07 & 2.57 \\
\cline { 2 - 5 } & Range & 1.92 to 2.93 & 1.73 to 3.58 & 2.11 to 2.93 \\
\hline \multirow{2}{*}{ Kidney } & Median & 2.17 & 2.61 & 2.65 \\
\cline { 2 - 5 } & Range & 1.83 to 2.84 & 2.18 to 2.77 & 0.75 to 3.37 \\
\hline \multirow{2}{*}{ Brain } & Median & 0.68 & 0.56 & 0.59 \\
\hline \multirow{2}{*}{ Lung } & Range & 0.49 to 3.90 & 0.45 to 0.76 & 1.04 \\
\hline
\end{tabular}

Each group consisted of 7 rats

* different than control P<0.05, Mann - Whitney U test 
is particularly important when organism's antioxidant defences are down (13). Anaesthetic drugs that cause less oxidative stress and have more antioxidant properties are therefore a better choice, especially in post-operative or critical patients who are already under increased oxidative stress $(14,15)$. Many studies have investigated antioxidative properties of intravenous anaesthetics, propofol in particular (1618). Oztürk et al. (19) and Nakahata et al. (20) found that propofol lowered oxidative stress, especially in rat brain. In a study on rats similar to ours, Abdelmajeed (21) found that intravenous diazepam increased oxidative damage to the rat liver, kidney, and heart, which was accompanied by increased nitric oxide (NO) levels.

Findings from animal studies on volatile anaesthetics and tissue oxidative stress are limited (22). Awad et al. (23) showed that halothane caused free radical formation and impaired rat liver antioxidant defences in vivo. Sato et al. (25) found that sevoflurane also had the potential to cause lipid peroxidation in vivo and in vitro. Similarly, SOD and GSH-Px levels in our study showed weaker antioxidative potential of sevoflurane and desflurane in rat liver and kidney, respectively.

Kudo et al. (24) studied antioxidant activity in rats with ischaemic brain injury treated with isoflurane, sevoflurane, and halothane. These volatile anaesthetics provided no direct protection against oxidative stress. This is similar to our finding that sevoflurane did not increase SOD and GSH-Px levels, and therefore provided no antioxidative protection of rat brain.

In swine lungs, desflurane seemed to induce local and systemic oxidative stress, whereas sevoflurane showed antioxidative properties (26). This is not consistent with our results, perhaps due to a different experimental design, as we did our research on rats and we did not mechanically ventilate them as Allaochiche et al. (26) did with swine. Our experimental design, which included controlled breathing environment and a relatively long time of exposure (4 hours), aimed to underline the relation between volatile anaesthetics and oxidative stress. What we have found out is that the lungs take the most of oxidative damage, being the first tissue exposed anaesthetic gas.

Our findings show that both sevoflurane and desflurane caused an increase in MDA levels only in the lung, while in other tissues they barely altered the activity of antioxidative enzymes. This suggests that anaesthesiologist should not only be aware of the oxidative or antioxidative potential of anaesthetics they use, but should also base their choices on organs which are the most affected by their oxidative action.

\section{REFERENCES}

1. McDermott JH. Antioxidant nutrients: current dietary recommendations and research update. J Am Pharm Assoc 2000;40:785-99.

2. McCord JM. The evaluation of free radicals and oxidative stress. Am J Med 2000;108:652-9.

3. Eroglu F, Yavuz L, Ceylan BG, Yilmaz F, Eroglu E, Delibas N, Nazıroğlu M. New volatile anesthetic, desflurane, reduces vitamin $\mathrm{E}$ level in blood of operative patients via oxidative stres. Cell Biochem Funct 2010;28:211-6.

4. Rükgauer M, Neugebauer RJ, Plecko T. The relation between selenium, zinc and copper concentration and the trace element dependent antioxidative status. J Trace Elem Med Biol 2001;15:73-8.

5. Fröba G. Alternativen zu Lachgas - Desfluran [Alternatives to nitrous oxide-desflurane, in German]. Anasthesiol Intensivmed Notfallmed Schmerzther 2001;36:646-8.

6. Conzen P. Sevofluran, Desfluran - und immer noch kein Ende! [Sevoflurane, desflurane: no end in sight! in German]. Anaesthesist 2000;49:867-8.

7. Whitford GM. The Metabolism and Toxicity of Fluoride. Monogr Oral Sci 1989;13:1-160.

8. Fitzgerald SP, Campell JJ, Lamount JV. The establishment of reference ranges for selenium. Selenoenzyme glutathione peroxidase and metalloenzyme superoxide dismutase in blood fractions. In: Proceedings of the Fifth International Syposium on Selenium in Biology and Medicine; 20-23 July 1992. Nashville (TN): Vanderbilt University; 1992. p. 203.

9. Pleban PA, Munyani A, Beachum J. Determination of selenium concentration and glutathione peroxidase activity in plasma and erythrocytes. Clin Chem 1982;28:311-6.

10. Jain SK. Hyperglycemia can cause membrane lipid peroxidation and osmotic fragility in human red blood cells. J Biol Chem 1989;264:21340-5.

11. Luterotti S, Žanić-Grubišić T, Juretić D. Rapid and simple method for the determination of copper, manganese, and zinc in rat liver by direct flame atomic absorption spectrometry. Analyst 1992;117:141-3.

12. Chi $\mathrm{CH}$, Shiesh SC, Lin XZ. Total antioxidant capacity and malondialdehyde in acute abdominal pain. Am J Emerg Med 2002;20:79-82.

13. Korenaga D, Takesue F, Kido K, Yasuda M, Inutsuka S, Honda M, Nagahama S. Impaired antioxidant defense system of colonic tissue and cancer development in dextran sulfate sodium-induced colitis in mice. J Surg Res 2002;102:144-9.

14. Tsuchiya M, Asada A, Maeda K, Ueda Y, Sato EF, Shindo M, Inoue M. Propofol versus midazolam regarding their antioxidant activities. Am J Respir Crit Care Med 2001;163:26-31.

15. Eger IE. The pharmacology of inhaled anesthetics. In: Seminars in Anesthesia, Perioperative Medicine and Pain. J Crit Care 2005;24:89-100. 
16. Dispersyn G, Pain L, Touitou Y. Propofol anesthesia significantly alters plasma blood levels of melatonin in rats. Anesthesiology 2010;112:333-7.

17. Menku A, Ogden M, Saraymen R. The protective effects of propofol and citicoline combination in experimental head injury in rats. Turk Neurosurg 2010;20:57-62.

18. Kambara T, Inada T, Kubo K, Shingu K. Propofol suppresses prostaglandin $\mathrm{E}(2)$ production in human peripheral monocytes. Immunopharmacol Immunotoxicol 2009;31:11726.

19. Oztürk E, Demirbilek S, Köroğlu A, But A, Begeç ZO, Gülec M, Akyol O, Ersoy MO. Propofol and erythropoietin antioxidant properties in rat brain injured tissue. Prog Neuropsychopharmacol Biol Psychiatry 2008;32:81-6.

20. Nakahata K, Kinoshita H, Azma T, Matsuda N, HamaTomioka K, Haba M, Hatano Y. Propofol restores brain microvascular function impaired by high glucose via the decrease in oxidative stress. Anesthesiology 2008;108:26975 .

21. Abdelmajeed NA. Diazepam-induced oxidative stress in rat different organs research. Res J Medicine \& Med Sci 2009;4:295-302.
22. Ceylan BG, Yilmaz F, Eroglu F, Yavuz L, Gulmen S, Vural H. Oxidant and antioxidant activities of different anesthetic techniques. Propofol versus desflurane. Saudi Med J 2009;30:371-6.

23. Awad JA, Horn JL, Roberts LJ, Franks JJ. Demonstration of halothane-induced hepatic lipid peroxidation in rats by quantification ofF2-isoprotanes. Anesthesiology 1996;84:9106 .

24. Kudo M, Aono M, Lee Y, Massey G, Pearlstein RD, Warner DS. Laboratory investigation absence of direct antioxidant effects from volatile anesthetics in primary mixed neuronalglial cultures. Anesthesiology 2001;94:303-12.

25. Sato N, Fujii K, Yuge O. In vivo and in vitro sevofluraneinduced lipid peroxidation in guinea-pig liver microsomes. Pharmacol Toxicol 1994;75:366-70.

26. Allaouchiche B, Debon R, Goudable J, Chassard D, Duflo F. Oxidative stress status during exposure to propofol, sevoflurane and desflurane. Anesth Analg 2001;93:981-5. 


\section{Sažetak \\ UTJECAJ DESFLURANA I SEVOFLURANA NA RAZINE OKSIDATIVNOG STRESA U TKIVIMA ŠTAKORA}

Poznato je da kirurške zahvate prati porast razine oksidativnog stresa, kako zbog stvaranja slobodnih kisikovih radikala tako i zbog smanjene aktivnosti obrambenih sustava koji se mogu oduprijeti njihovu djelovanju. Stoga su saznanja o antioksidativnom kapacitetu anestetika koji se primjenjuju prije nekoga kirurškog zahvata vrlo važna i od velikog su kliničkog značenja. Sevofluran i desfluran su inhalacijski anestetici koji se učestalo rabe u svrhu uvođenja bolesnika u anesteziju. Cilj ovog istraživanja bio je utvrditi razine oksidativnog stresa u različitim tkivima štakora i usporediti razlike u odgovoru tkiva na izlaganje navedenim anesteticima. $U$ tu svrhu razine oksidativnog stresa izmjerili smo u jetri, mozgu, bubrezima i plućima štakora podijeljenih u tri eksperimentalne skupine. Kontrolna skupina udisala je samo zrak, dok su druge dvije skupine izložene $8 \%$-tnomu sevofluranu te $4 \%$-tnomu desfluranu tijekom $4 \mathrm{~h}$. Nakon završetka obrade životinje su žrtvovane i uzimani su im uzorci tkiva za biokemijske analize. Mjerena je razina malondialdehida (MDA), aktivnost enzima superoksid dismutaze (SOD) i glutation peroksidaze (GSH-Px) te razine bakra i cinka. Izloženost anesteticima izazvala je oksidativni stres u plućima, na što upućuje značajno povišena razina MDA (Mann-Whitney U-test $\mathrm{P}<0.05$ ) izmjerena u plućnom tkivu štakora obiju izloženih skupina u odnosu na kontrolu. Plućno je tkivo u odnosu na ostala tkiva podložnije štetnim utjecajima reaktivnih kisikovih radikala vjerojatno stoga što je ono prvo izloženo plinovitim anesteticima nakon njihova ulaska u organizam. Razine oksidativnog stresa i antioksidativne aktivnosti koje smo izmjerili u ostalim tkivima bile su različite te su ovisile o primijenjenom anestetiku. Na osnovi dobivenih rezultata možemo zaključiti da bi se zbog različitog odgovora tkiva izbor anestetika trebao provoditi na individualnoj osnovi.

KLJUČNE RIJEČI: Cu, glutation peroksidaza, malondialdehid, reaktivni kisikovi radikali, superoksid dismutaza, inhalacijski anestetici, $\mathrm{Zn}$

\section{CORRESPONDING AUTHOR:}

Professor Bensu Karahalil, PhD

Gazi University, Faculty of Pharmacy

Toxicology Department

Ankara, 06330, TURKEY

E-mail:bensuka@gmail.com; bensu@gazi.edu.tr 